\title{
PENGARUH MODEL PROBING PROMPTING TERHADAP HASIL BELAJAR KOGNITIF SISWA PADA MATERI PEWARISAN SIFAT
}

\author{
Hilarius Jago Duda', Fitri Hamiani Adibah², Didin Syafruddin ${ }^{3}$

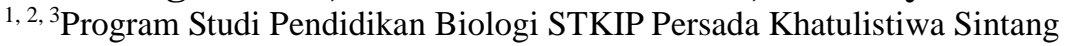 \\ Jalan Pertamina-Sengkuang Sintang \\ 1e-mail: fitriadibah5@gmail.com
}

\begin{abstract}
Abstrak
Tujuan penelitian adalah untuk mengetahui pengaruh model pembelajaran Probing Prompting terhadap hasil belajar kognitif siswa kelas IX SMPN 3 Silat Hilir pada materi Pewarisan Sifat. Metode penelitian adalah eksperimen semu dengan desain penelitian Nonequevalent Control Group. Sampel yang digunakan ada dua kelas dengan jumlah siswa perkelas adalah 24. Alat pengumpul data adalah lembar observasi, soal tes, dan angket. Analisis data dengan anlisis statistik dan persentase. Rata-rata persentase hasil observasi pada kelas eksperimen adalah 95,30\% dan dan kelas kontrol 97,16\% keduanya masuk dalam kategori "baik". Hasil analisis data diperoleh nilai rata-rata post-test kelas eksperimen 77,50. Sedangkan pada kelas kontrol diperoleh nilai rata-rata post-test sebesar 58,12. Data hasil angket diperoleh persentase sebesar 75\% masuk dalam kategori "baik". Setelah dilakukan uji hipotesis diperoleh nilai $t_{\text {hitung }} 2,45$ lebih besar dari $t_{\text {tabel }} 2,01$, sehingga Ho ditolak. Jadi penerapan model pembelajaran Probing Prompting berpengaruh signifikan terhadap hasil belajar kognitif siswa pada mata pelajaran IPA Terpadu khususnya materi pewarisan sifat.
\end{abstract}

Kata Kunci: Probing Prompting, hasil belajar, kognitif.

\begin{abstract}
s
The objective of this study was to determine the influence of Probing Prompting learning model on the student's cognitive learning outcome at students class IX SMPN 3 Silat Hilir on the learning material inheritance of the nature. The research method used quasi experiment with nonequivalent control group design. The sample used there are two classes with the number of students class is 24. Data collection tool is an observation sheet, test questions and questionnaires. Data analysis with statistical analysis and percentage. The average percentage of observations in the experimental class is $95.30 \%$ and the control class $97.16 \%$ both are in the "good" category. The result of data anliysis obtained the average value of post-tes experimental class 77,50, while in the control class obtained the average post-test value of 58,12. Questionnarie data obtained percentage of $75 \%$ fall into the category of "good". After the hyopthesis test obtained $t$ value 2,45462 $\geq t$ tabel 2,01290, So (Ha) accepted and (Ho) rejected. If can be concluded that the application of learning model of Probing Prompting has a significant effect on students cognitive learning outcomes on integrated IPA subjects pasrticularly inheritance properties.
\end{abstract}

Keywords: Probing Prompting, learning outcome, cognitive.

\section{PENDAHULUAN}

Proses belajar mengajar pada hakekatnya merupakan proses interaksi antara siswa dan guru serta siswa dengan siswa. Makin kreatif seorang guru dalam 
memilih model dan media pembelajaran yang digunakan dalam kegiatan pembelajaran dan menggunakan cara bervariasi sesuai materi secara langsung dapat mempengaruhi hasil belajar siswa.

Hasil belajar menurut Winkel (Purwanto, 2011: 45) adalah "Perubahan yang mengakibatkan manusia berubah dalam sikap dan tingkah lakunya". Sedangkan menurut Sudjana (2011: 22), "Hasil belajar adalah kemampuan-kemampuan yang telah dimiliki siswa setelah ia menerima pengalaman belajarnya". Hasil belajar mencakup aspek kognitif, keterampilan, dan sikap yang dimiliki siswa tersebut meningkat atau berubah ke arah yang lebih positif atau baik dari sebelumnya karena adanya proses belajar.

Hasil belajar kognitif merupakan sebuah hasil yang diperoleh siswa setelah proses pembelajaran berupa pengetahuan atau ilmu yang dikuasainya dalam jangka waktu tertentu. Berdasarkan uraian tersebut dapat disimpulkan bahwa hasil balajar merupakan penilaian kemampuan-kemampuan yang telah dimilki siswa dari hasil usaha kegiatan belajar yang dinyatakan dalam bentuk simbol, angka, huruf maupun kalimat yang dapat mencerminkan hasil yang sudah dicapai oleh setiap siswa. Ranah kognitif menurut Bloom berkenaan dengan hasil belajar yang terdiri dari enam aspek, yaitu: pengetahuan $(\mathrm{C} 1)$, pemahaman $(\mathrm{C} 2)$, penerapan (C3), analisis (C4), evaluasi (C5), dan menciptakan (C6).

Berdasarkan pra-observasi di SMP Negeri 3 Silat Hilir ditemukan masalah dalam proses pembelajaran pada mata pelajaran IPA di kelas IX. Proses pembelajaran tersebut berjalan kurang efektif, kebanyakan siswa lebih pasif, enggan berbicara, malu untuk mengemukakan pendapatnya sendiri dan ada juga beberapa orang siswa mengobrol dengan teman sebangkunya. Akibatnya, siswa kurang memahami materi pelajaran. Siswa juga terlihat kurang antusias dalam mengikuti kegiatan pembelajaran pada mata pelajaran IPA yang belum dilaksanakan dengan langkah-langkah sistematis serta masih menggunakan metode dan model pembelajaran dengan sistem ceramah. Tentu saja aktivitas siswa tersebut akan mengganggu kegiatan pembelajaran di kelas dan berdampak pada tidak tercapainya ketuntasan belajar siswa. Oleh karenanya, peneliti mecoba menggunakan model lain untuk dapat memotivasi siswa dalam belajar dan dapat 
meningkatkan kognitif siswa. Salah satu model pembelajaran yang dipilih dalam penelitian tersebut adalah model pembelajaran Probing Prompting.

Menurut Suyatno (2009: 63), "Model pembelajaran Probing Prompting merupakan suatu model pembelajaran dengan menyajikan serangkaian pertanyaan yang sifatnya menuntun dan menggali sehingga terjadi proses berpikir yang mengaitkan pengetahuan setiap siswa. Dimana dalam pembelajaran dengan model tersebut kemampuan berpikir siswa diberdayakan untuk mengetahui tentang materi yang dipelajarinya.

Model pembelajaran Probing Prompting diharapkan mampu meningkatkan prestasi dan menarik perhatian siswa. Model pembelajaran Probing Prompting merupakan sebuah kegiatan pembelajaran yang menyajikan serangkaian pertanyaan yang bersifat menggali dan menuntun sehingga akan terjadi proses berpikir yang mengaitkan pengetahuan yang telah dipelajari dengan pengetahuan baru yang sedang dipelajari.

Model pembelajaran Probing Prompting dipandang sangat cocok untuk meningkatkan hasil belajar kognitif siswa pada pelajaran IPA terpadu materi pewarisan sifat kelas IX. Melalui model pembelajaran Probing Prompting, siswa termotivasi untuk berpikir dan menjawab, sehingga pelajaran IPA terpadu pada materi pewarisan sifat yang dianggap sulit akan berubah menjadi pelajaran yang menyenangkan. Pada kegiatan pembelajaran, guru dan siswa memiliki peran yang sama aktif. Pewarisan sifat adalah ciri-ciri atau sifat-sifat makhluk hidup yang diturunkan dari generasi ke generasi.

Berdasarkan latar belakang yang telah diuraikan, penulis melakukan penelitian dengan judul "Pengaruh Model Pembelajaran Probing Prompting terhadap Hasil Belajar Kognitif Siswa pada Materi Pewarisan Sifat Kelas IX SMP Negeri 3 Silat Hilir Tahun Pelajaran 2017/2018”.

\section{METODE}

Pendekatan penelitian yang digunakan adalah pendekatan kuantitatif. Metode penelitian yang digunakan adalah metode eksperimen. Bentuk penelitian adalah Quasy experiment. Quasy experiment adalah desain penelitian yang 
menggunakan dua kelas, yaitu kelas eksperimen sebagai subjek penelitian, dan kelas kontrol sebagai pembandingnya.

Populasi dalam penelitian adalah seluruh siswa kelas IXA dan IXB SMPN 3 Silat Hilir dengan teknik Nonprobability Sampling. Sampel penelitian diambil dengan teknik sampel jenuh, yaitu teknik penentuan sampel yang semua anggota populasi digunakan menjadi sampel. Siswa kelas IXA sebagai kelas eksperimen dan kelas IXB sebagai kelas kontrol karena dari kedua kelas tersebut memiliki kemampuan yang tidak jauh berbeda, misalnya dari segi kemampuan ada yang tinggi, sedang, dan ada juga yang memiliki kemampuan rendah. Penentuan kelas eksperimen dan kontrol dilakukan dengan cara diundi, dengan alasan kemampuan awal kedua kelas tersebut sama. Kelas eksperimen diajarkan menggunakan model Probing Prompting dan kelas kontrol menggunakan ceramah.

Teknik pengumpulan data yang digunakan adalah teknik observasi langsung, teknik pengukuran, dan teknik komunikasi tidak langsung. Alat pengumpulan data yang digunakan adalah lembar observasi keterlaksanaan model pembelajaran, soal tes, dan lembar angket tanggapan terhadap penggunaan model pembelajaran. Teknik analisis data berupa: (1) Analisis lembar observasi; (2) Analisis hasil tes meliputi uji normalitas, uji homogenitas, uji hipotesis menggunakan uji t dua sampel; dan (3) Analisis hasil angket.

\section{HASIL DAN PEMBAHASAN}

Berdasarkan hasil observasi yang dilakukan observer terhadap guru di kelas eksperimen yang mengajar dengan menerapkan model pembelajaran Probing Prompting menunjukkan bahwa guru telah melaksanakan langkah pembelajaran secara tepat.

Pertemuan pertama pada siswa kelas eksperimen diperoleh nilai rata-rata keterlaksanaan observasi dengan persentase sebesar 93,38\% dan pertemuan kedua sebesar 97,22\%. Setelah dilakukan analisis persentase keseluruhan dari pertemuan pertama dan kedua kelas eksperimen diperoleh nilai rata-rata keterlaksanaan observasi adalah 95,30\%. Pada kelas kontrol hasil observasi menunjukkan bahwa pada pertemuan pertama siswa kelas kontrol memperoleh nilai sebesar 97,21\% 
dan pertemuan kedua 97,11\% dengan hasil akhir yaitu 97,16\%. Jadi, dapat disimpulkan bahwa seluruh kegiatan siswa mulai dari kegiatan awal, kegiatan inti, dan penutup telah dilaksanakan sesuai dengan langkah-langkah yang sudah ditetapkan pada rencana pelaksanaan pembelajaran.

Hasil observasi siswa di kelas eksperimen pada pertemuan pertama dan pertemuan kedua yang diamati oleh kedua observer dengan jumlah siswa 24 orang, terlihat bahwa siswa memperhatikan penjelasan oleh guru pada saat proses pembelajaran berlangsung. Berdasarkan analisis observasi guru pada pertemuan pertama dan kedua pada kelas eksperimen didapatkan kriteria baik. Artinya, guru telah melaksanakan pembelajaran sesuai dengan tahap-tahap model Probing Prompting yang ditentukan secara baik sesuai dengan rangkaian kegiatan pembelajaran yang terdapat pada langkah-langkah penerapan metode pembelajaran tersebut.

Hasil observasi siswa di kelas kontrol pada pertemuan pertama dan pertemuan kedua yang diamati oleh kedua observer dengan jumlah siswa 24 orang, terlihat bahwa siswa memperhatikan penjelasan guru pada saat proses pembelajaran berlangsung. Dimana guru sudah melaksanakan tahap pembelajaran konvensional dengan baik. Jadi, dengan demikian dapat dijelaskan bahwa seluruh kegiatan siswa mulai dari kegiatan awal, kegiatan inti, dan penutup untuk kedua kelas tersebut telah dilaksanakan sesuai dengan langkah-langkah yang sudah ditetapkan pada rencana pelaksanaan pembelajaran.

Pelaksanaan pre-test dan post-test diikuti oleh 24 siswa di kelas eksperimen dan 24 siswa di kelas kontrol. Hasil tes kognitif siswa kelas eksperimen dan siswa kelas kontrol dapat dilihat pada Tabel 1. Hasil uji hipotesis post-test eksperimen dan kontrol dapat dilihat pada Tabel 2.

Tabel 1 Hasil Tes Kognitif Siswa

\begin{tabular}{ccccc}
\hline \multirow{2}{*}{ Nilai } & \multicolumn{2}{c}{ Kelas Eksperimen } & \multicolumn{2}{c}{ Kelas Kontrol } \\
\cline { 2 - 5 } & Pre-test & Post-test & Pre-test & Post-test \\
\hline Nilai tertinggi & 60 & 90 & 60 & 75 \\
Nilai terendah & 30 & 60 & 30 & 50 \\
Nilai Rata-rata & 49,59 & 77,50 & 50,21 & 58,12 \\
Standar deviasi & 8,59 & 8,47 & 7,44 & 7,49 \\
\hline
\end{tabular}


Tabel 2 Hasil Uji t Data Post-Test Eksperimen Kontrol

\begin{tabular}{ccccc}
\hline Post-Test & Dk & T hitung & T tabel & Keterangan \\
\hline $\begin{array}{c}\text { Eksperimen } \\
\text { Kontrol }\end{array}$ & 46 & 2,45 & 2,01 & $\begin{array}{c}\mathrm{H}_{\mathrm{a}} \text { diterima dan } \mathrm{H}_{0} \\
\text { ditolak }\end{array}$ \\
\hline
\end{tabular}

Berdasarkan hasil uji normalitas data, data pre-test dan data post-test pada kelas eksperimen dan kelas kontrol berdistribusi normal. Artinya, semua data tersebar secara merata dari jumlah anggota sampel. Hasil uji homogenitas antara kelas eksperimen dan kelas kontrol terlihat data kedua varians homogen antara nilai pre-test dan post-test. Oleh karena data berdistribusi normal dan homogen, maka langkah selanjutnya adalah dengan melakukan uji hipotesis yaitu uji statistik parametrik dengan menggunakan uji t. Uji hipotesis digunakan untuk mengetahui apakah terdapat perbedaan atau tidak antara kelas eksperimen yang diajar dengan model pembelajaran Probing Prompting dengan kelas kontrol yang diajar dengan menerapkan pembelajaran konvensional.

Langkah perhitungan statistik parametrik yaitu yang pertama dengan mencari nilai $t_{\text {hitung }}$ dan $t_{\text {tabel,. }}$ Selanjutnya, menarik kesimpulan dari hasil $t_{\text {hitung }}$ dan $\mathrm{t}_{\text {tabel }}$ tersebut. Nilai post-test kelas eksperimen dan kelas kontrol menghasilkan $t_{\text {hitung }} 2,45$ dan nilai $t_{\text {tabel }}$ 2,01. Dikarenakan $t_{\text {hitung }}$ lebih besar dari $t_{\text {tabel }}$, sehingga Ho ditolak. Hal tersebut berarti bahwa terdapat perbedaan yang signifikan antara model pembelajaran Probing Prompting dengan model pembelajaran ceramah terhadap hasil belajar kognitif siswa.

Hasil belajar kognitif siswa kelas eksperimen lebih tinggi, hal tesebut dikarenakan siswa terlibat aktif dalam pembelajaran. Rohiat (Benny, dkk., 2017) menyatakan bahwa dalam proses belajar mengajar, seorang guru harus berperan sebagai fasilitator. Seorang guru berperan mengontrol kegiatan siswa dalam belajar. Sedangkan proses pembelajaran banyak diambil alih oleh siswa. Siswa harus aktif dalam bertanya, menjawab pertanyaan, berbicara, dan lain sebagainya.

Snyder (Duda, 2015) menyatakan bahwa hambatan dalam berpikir siswa adalah pembelajaran instruksi langsung atau ceramah, kurang melaksanakan kegiatan pelatihan atau eksperimen, sumber daya yang terbatas, prasangka bias, 
keterbatasan waktu dalam bekerja sama, dan kurang memanfaatkan lingkungan belajar yang memberdayakan kemampuan berpikir sehingga dengan demikian penguasan konsep siswa rendah. Menurut Benny, dkk. (2017) dikarenakan kurangnya keseriusan dalam belajar, pengetahuan yang minim serta kecenderungan guru menggunakan metode ceramah dan penugasan, sehingga menyebabkan kurangnya minat belajar siswa dan menyebabkan minimnya pengetahuan dan pemahaman siswa.

Kriteria angket keterlaksanaan model pembelajaran yaitu ya atau tidak dengan skor ya $=1$ dan tidak $=0$. Skor maksimal dari setiap pernyataan adalah 1 dan jumlah skor adalah 24 (hasil $24 \times 1=24$ ). Rekapitulasi hasil angket dapat dilihat pada tabel berikut.

Tabel 3 Rekapitulasi Hasil Analisis Data Angket Respon Siswa

\begin{tabular}{cccc}
\hline Pernyataan & \multicolumn{2}{c}{ Persentase } & \multirow{2}{*}{ Kriteria Penilaian } \\
\cline { 2 - 3 } & Ya & Tidak & \\
\hline Jumlah persentase & $1125 \%$ & $282 \%$ & \multirow{2}{*}{ Baik } \\
Persentase rata-rata & $75 \%$ & $25 \%$ & \\
\hline
\end{tabular}

Keterangan: ya = setuju penggunaan model.

Tidak = tidak setuju penggunaan model.

Kelebihan penelitian yaitu siswa menjadi lebih aktif, adanya penambahan waktu pembelajaran, hasil belajar kognitif siswa mengalami peningkatan yang signifikan, pertemuan pertama siswa belum terbiasa dengan penggunaan model Probing Prompting sehingga peneliti harus berusaha semaksimal mungkin dalam mengorganisir siswa untuk melaksanakan langkah-langkah pembelajaran yang sesuai dengan model Probing Prompting. Sedangkan kelemahan penelitian yaitu karena model Probing Prompting baru bagi kelas tersebut dengan tahap-tahap yang berbeda dari biasanya, maka ada beberapa siswa yang kebingungan saat proses pembelajaran berlangsung dan masih kurang memperhatikan penjelasan guru dengan baik karena banyak pertanyaan yang diberikan guru yang merupakan salah satu ciri dari model tersebut. 


\section{SIMPULAN}

Berdasarkan analisis data yang telah dilakukan, maka dapat disimpulkan: (1) Proses pembelajaran oleh guru dengan diterapkannya model pembelajaran Probing Prompting pada materi Pewarisan Sifat berlangsung dengan baik. Hal tersebut berdasarkan pada hasil persentasi lembar observasi dari observer yang menunjukkan nilai rata-rata persentase sebesar 95,30\% dan masuk kategori baik;

(2) Pada pre-test dan post-test kelas eksperimen, didapat skor pre-test 49,59 dan post-test 77,50. Hasil tersebut mengalami kenaikan sebesar 27,91 sehingga dapat dikatakan bahwa model pembelajaran Probing Prompting dapat meningkatkan hasil belajar kognitif siswa; (3) Pada pre-test dan post-test kelas kontrol, didapat skor pre-test 50,21 dan post-test 58,12. Hasil tersebut mengalami kenaikan sebesar 7,91, kenaikan skor dan skor rata-rata kelas kontrol lebih rendah dibandingkan dengan rata-rata kelas eksperimen sehingga dapat dikatakan model ceramah pada kelas kontrol kurang efektif dibandingkan model pada kelas eksperimen dengan diterapkannya model pembelajaran Probing Prompting; (4) Terdapat perbedaan yang signifikan dari penerapan model pembelajaran Probing Prompting terhadap pengaruh hasil belajar kognitif siswa pada materi pewarisan sifat yang diperoleh dari hasil $t_{\text {hitung }}$ 2,45-lebih besar dari $\mathrm{t}_{\text {tabel }} 2,01$ sehingga $\mathrm{H}_{0}$ ditolak; dan (5) Berdasarkan angket respon siswa diperoleh persentase rata-rata respon positif (ya) sebesar $75 \%$. Hasil respon positif terhadap penggunaan model pembelajaran Probing Prompting tersebut kategori baik.

\section{DAFTAR PUSTAKA}

Abdurokhim, M. 2015. Keefektifan Model Probing-Prompting dalam Pembelajaran Sejarah Uang pada Siswa Kelas III SD Negeri Kepandean 3 Kabupaten Tegal. Skripsi. Jurusan Pendidikan Guru Sekolah Dasar. Universitas Negeri Semarang.

Arikunto, S. 2013. Prosedur Penelitian Suatu Pendekatan Praktik. Jakarta: Rineka Cipta.

Benny, Y., Duda, H. J., Sirhi, S. 2017. Improving Students' Learning Results Using The Study Group Method On Structure And Functions Of Plants In Fourth Grade. Scholaria, Vol 7 No 2, Mei 2017: 126-134.

Duda, H. J. 2015. Pengaruh Model Pembelajaran Berbasis Masalah melalui 
Praktikum yang Ditunjang Asesmen Autentik dan Etnis terhadap Kemampuan Berpikir Kritis, Keterampilan Proses Sains, dan Sikap Ilmiah Mahasiswa STKIP Persada Khatulistiwa Sintang pada Mata Kuliah Fisiologi. Disertasi. Universitas Negeri Malang. Tidak diterbitkan.

Huda, M. 2014. Model-model Pembelajaran dan Pengajaran. Yogyakarta: Pustaka Pelajar.

Kusrini. 2015. Efektivitas Model Cooperatif Learning Tipe Teams Game Tournament terhadap Kemampun Berpikir Kritis dan Hasil Belajar Siswa Kelas XI MIA Pada Pokok Bahasan Sel. Skripsi. Sintang: STKIP Persada Khatulistiwa.

Purwanto, M. N. 2009. Prinsip-Prinsip dan Teknik Evaluasi Pembelajaran. Bandung: Remaja Rosdakarya.

Sudjana, N. 2011. Penelitian Hasil Proses Belajar Mengajar. Bandung: Remaja Rosdakarya.

Sudjana, N. 2013. Penilaian Hasil Proses Belajar Mengajar. Bandung: Remaja Rosdakarya.

Sugiyono. 2011. Metode Penelitian Pendidikan Pendekatan Kuantitatif Kualitatif dan $R \& D$. Bandung: Alfabeta.

Sugiyono. 2013. Metode Penelitian Pendidikan (Pendekatan Kuantitatif, Kualitatif, dan $R \& D)$. Bandung: Alfabeta.

Suyatno. 2009. Menjelajah Pembelajaran Inovatif. Sidoarjo: Masmedia Buana Pustaka.

Trianto. 2009. Mendesain Model Pembelajaran Inovatif-Progresif. Jakarta: Kencana Prenada Media Group.

Widoyoko, E. P. 2014. Penilaian Hasil Pembelajaran di Sekolah. Yogyakarta: Pustaka Pelajar. 